\title{
URBAN RESILIENCE
}

Edward L. Glaeser

Working Paper 29261

http://www.nber.org/papers/w29261

\author{
NATIONAL BUREAU OF ECONOMIC RESEARCH \\ 1050 Massachusetts Avenue \\ Cambridge, MA 02138 \\ September 2021
}

I am grateful to Abigail Power for editorial assistance. The views expressed herein are those of the author and do not necessarily reflect the views of the National Bureau of Economic Research.

The author has disclosed additional relationships of potential relevance for this research. Further information is available online at http://www.nber.org/papers/w29261.ack

NBER working papers are circulated for discussion and comment purposes. They have not been peer-reviewed or been subject to the review by the NBER Board of Directors that accompanies official NBER publications.

(C) 2021 by Edward L. Glaeser. All rights reserved. Short sections of text, not to exceed two paragraphs, may be quoted without explicit permission provided that full credit, including () notice, is given to the source. 
Urban Resilience

Edward L. Glaeser

NBER Working Paper No. 29261

September 2021

JEL No. R11,R23,R28,R5,R53,R58

\begin{abstract}
$\underline{\text { ABSTRACT }}$
Will COVID-19 end the urban renaissance that many cities have experienced since the 1980s? This essay selectively reviews the copious literature that now exists on the long-term impact of natural disasters. At this point, the long-run resilience of cities to many forms of physical destruction, including bombing, earthquakes and fires, has been well-documented. The destruction of human capital may leave a longer imprint, but cities have persisted through many plagues over the past millennia. By contrast, economic and political shocks, including deindustrialization or the loss of capital city status, can enormously harm an urban area. These facts suggest that the COVID-19 pandemic will only significantly alter urban fortunes, if it is accompanied by a major economic shift, such as widespread adoption of remote work, or political shifts that could lead businesses and the wealthy to leave urban areas. The combination of an increased ability to relocate with increased local redistribution or deterioration of local amenity levels or both could recreate some of the key attributes of the urban crisis of the 1970s.
\end{abstract}

Edward L. Glaeser

Department of Economics

315A Littauer Center

Harvard University

Cambridge, MA 02138

and NBER

eglaeser@harvard.edu 


\section{Introduction}

How resilient will the world's cities be to the COVID-19 pandemic and the risk of future global outbreaks? The long view of urban resilience suggests that cities are far more vulnerable to economic and political dislocation than to earthquakes, wars and even pandemics. The most consequential catastrophes are those that fragment existing institutions and economies, which is why the strength of civil society determines the consequences of any disaster. The COVID-19 pandemic is dangerous for the world's cities because it has exacerbated existing challenges, including adapting to virtual life and the political instability associated with growing urban discontent (Glaeser, 2020). The two threats may work together, because just like highways during the 1960s, telecommuting enables the flight from faltering central cities. ${ }^{1}$

Section II of this paper argues that for the past 650 years, cities have been remarkably resilient to standard physical threats. I do not mean to suggest that cities do not experience enormous human carnage and destruction, or that physical threats should be ignored in any way. I mean instead to claim that cities generally recover their populations and economic vitality after those physical shocks, and generally resume their place in the urban hierarchy.

Cities readily rebuild themselves after catastrophic earthquakes and bomb attacks (Davis and Weinstein, 2002). The epidemics that blazed through western cities from the 1790s to 1919 did little to stem their growth, and even the Black Death had little impact on urban populations in the long run (Jedwab et al., 2019). The fires that destroyed swaths of London in 1666, Chicago in 1871 and Boston in 1872 may have even strengthened those cities by allowing for a more efficient use of space (Hornbeck and Keniston, 2017).

Yet economic and political dislocation have often led to long periods of urban decline, which I discuss in Section III. The opening of the Panama Canal badly reduced the economic relevance of the Chilean port of Valparaiso, and the city's "growth was stunted like a seed planted too late in the season and surprised by the frost of winter” (Calderon, 2001). Former manufacturing and

\footnotetext{
${ }^{1}$ Highways led to a population decline of central cities (Baum-Snow, 2007), which in turn hastened the political crises of the 1970s. They did not lead to a decline in the overall size of metropolitan areas. Similarly, telecommuting may well lead to a decline in the relative importance of the city center but an expansion in the periphery of the most productive metropolitan areas.
} 
maritime powerhouses like Cleveland and Liverpool, have less than one-half of their past populations, because their erstwhile industrial employers have relocated or automated or just disappeared. Imperial capitals have often faded, either when the empire falters, as with Rome, or when the emperor dictates a change of venue, as with Chang'an.

This divergence between resilience to physical shocks and vulnerability to economic and political headwinds reminds us that cities are more than their structures. If those structures are destroyed, but there remains a good reason to live and work in that place, then the cities can be rebuilt. Even if the structures remain, the population will depart if there is neither an economic engine of prosperity or political patronage (Glaeser and Gyourko, 2005).

Yet there are exceptions to this general rule of resilience to physical disasters, and Section IV reviews several of them. The Plague of Athens, which struck in 430 B.C.E., seems to have played a significant role in that city's eventual defeat by Sparta in the Peloponnesian War and ultimate decline as a military and cultural powerhouse. Arguably, the Plague of Justinian, which struck Constantinople in 541 C.E., did even more damage to urban civilization in Europe. Medieval Dunwich shrank from a major port to a small village because of coastal erosion. The silting of the Zwijn estuary made it impossible for Bruges to maintain its importance as a trading capital of Northern Renaissance Europe. The Detroit Riots of 1967 helped hasten that city’s decline, by encouraging white flight and local political extremism. ${ }^{2}$

The lesson of this history for the COVID-19 pandemic is that the disease itself is likely to have a long-term effect only if it unleashes other economic and political forces that can engender urban decline. Section V of this paper highlights urban weaknesses that preceded the pandemic and then discusses two possible risks. Long before COVID urban shops had been facing reducing demand because of e-commerce. The pandemic induced many more people to shop for a much wider range of products online. The pandemic also increased telecommuting which imperils urban office markets (Bloom et al., 2021).

\footnotetext{
2 The city of Detroit has, like most rustbelt cities, declined far more than the Detroit metropolitan area as a whole, which continues to house over four million people. Yet even at the metropolitan area level, Detroit has gone from being wealthier than the average metropolitan area in the 1960s to being poorer than the average metropolitan area today.
} 
These forces create post-pandemic economic risks for cities, but many of the forces that kept people face-to-face in 2019 will remain after COVID-19. Our knowledge-intensive economy favors learning, and learning is easier face-to-face. Even studies that document the short run productivity of remote workers find that they are less likely to be promoted to more senior positions, possibly because they are not acquiring the skills that they need to move up. New hiring for jobs that had gone remote remained remarkably low during the pandemic, which suggests that firms were wary about integrating new workers into their cultures. Moreover, the difficulty of monitoring remote workers can make it hard to ensure high levels of effort, especially when output is hard to measure.

But the pandemic has also hit cities during a period of discontent over gentrification, racial disparities in policing and inequality more generally, and that creates political risks. The tract level data provided by Chetty et al. (2020) show that in America upward mobility is now far lower in dense urban areas. These real urban problems could set the stage for fractious political action, which could then engender out-migration. Even if people remain in offices, it is certainly far easier for those offices to relocate in order to find a friendlier business climate. If cities try to target their wealthier residents and businesses or if those cities allow urban crime levels to soar, then those taxpayers could easily leave, which in turn could generate a downward spiral, reminiscent of many American cities during the 1970s.

The economic risks created by telecommuting are common to all wealthy cities. The political risks are more severe in some places than others. In the northwestern parts of the EU, the national welfare state is generally strong, urban service levels are high and local autonomy is limited. Consequently, it is unlikely that the cities of the Germany, the Netherlands or Sweden will either levy punitive taxes on their businesses or allow the urban quality of life to collapse. In the UK and some southern EU countries, the welfare state is more frayed and there is more chance that urban amenities will be allowed to decline, but local governments typically lack the power to raise taxes arbitrarily and there is at least some national commitment to provide decent local services. The US has high levels of local autonomy and terrible history of slavery and racism, Many US cities, like Baltimore, had crime problems before COVID-19 struck. The history of Detroit discussed in Section IV suggests that American city governments can do great harm to their cities. Consequently, Section V focuses on the political risks facing US cities. Section VI concludes. I 
end by noting that while individual cities are vulnerable, I have little doubt that urban life will, by and large, continue in its full vitality.

\section{Urban Resilience to Physical Damage}

In this section, we make the claim that cities have typically been quite resilient to damage from earthquakes, bombs, fires and even plagues. I do not mean to suggest that these natural and manmade catastrophes have not wrought enormous numbers of deaths and required vast rebuilding efforts. In this paper, I mean resilience in a purely place-based sense, so that a city is resilient to a shock if it has recovered its population, economic vitality and most of its physical structures after a period of time.

Davis and Weinstein (2002) initiated the modern empirical literature on this form of urban resilience with their work on the bombing of Japanese cities during World War II. They framed their paper as a test between "random growth" and "locational fundamentals." If the "random growth" theory was correct, then there would be little reason for cities to bounce back after they were shelled. If city size was instead determined by "locational fundamentals," then the positive attributes that made the city large before bombing should presumably make the city expand again after bombing.

That persistence of local fundamentals, such as access to riverways or a rich hinterland, provides one explanation for why cities have largely displayed resilience to physical damage over the medium run. Another explanation is that central governments sometimes make a concerted effort to rebuild after the destruction. A third explanation is urban populations have increased dramatically over the past 600 years, and so the robust demand for urban space has made it possible to rebuild. It is far less obvious that cities would be rebuilt in an age of population loss and deurbanization.

We first turn to the impact of bombing and wartime deaths on urban trajectories. We then turn to fires and earthquakes. We end this section with plagues. Bombing, fires and earthquakes typically destroy as much or more physical than human capital. Disease kills but leaves the physical capital alone. As such, the first two subsections can be seen as focusing on the ability of cities to recover 
from a loss of buildings and infrastructure and the third subsection is best understood as addressing the urban ability to survive loss of life.

\section{Recovery from Wartime Damage}

Large-scale bombing efforts provides a relatively straightforward environment to test the impact of physical destruction on long-run urban outcomes. Many cities are bombed at roughly the same time, rather than the more usual one-off natural disasters. Some cities are bombed far more heavily than others. Moreover, the level of wartime bombing is driven more by military exigencies than post-war economic fundamentals and the risk of bombing disappears once the war has vanished.

Davis and Weinstein's (2002) basic specification is to regress the growth of population in Japanese between 1947 and 1960 on the change in population between 1940 and 1947. They instrument for the population change between 1940 and 1947 with the number of deaths and buildings destroyed by US bombing during World War II. Their primary coefficient estimates center around -1 , meaning that the entire impact of the war on city size had disappeared by 1960. They also look specifically at Hiroshima and Nagasaki and show that Nagasaki rejoined its pre-war trend line by 1960. Hiroshima took until the mid-1970s to attain the population predicted by its pre-war growth.

The Davis and Weinstein (2002) paper has spawned a body of literature which has typically corroborated these results in different settings. Brakman, Garretsen and Schramm (2004) examine the post-war recovery of German cities, usually essentially identical methods. The most directly comparable regression, controlling also for government reconstruction expenditure, is -.58, but this includes only West German cities. Without controlling for reconstruction, the coefficient is .52. These coefficients implies that the majority of the population loss was reversed by 1961 .

The slower level of convergence in Germany may reflect a slower rate of urban growth in that country. Between 1940 and 1960, the number of Japanese living in localities with more than 20,000 inhabitants rose by 56 percent, from 27.5 million to 42.9 million. The number of Germans, in the parts of the country that became West Germany, living in these larger communities increased by 35 percent from 20.3 million to 27.5 million, partially because of the flood of East German immigrants who moved west (United Nations Department of Economic and Social Affairs, 1969). 
New urbanites create demand for rebuilding, so it is reasonable that the country with more urban growth also experienced the quicker urban comebacks after World War II.

The total urban population of East Germany actually declined from 1940 to 1960, which may explain why Brakman et al. (2004) find a coefficient of 0 for East German cities, meaning that there was no tendency to recover their lost populations. They explain the difference between east and west by noting that "following Glaeser and Gyourko (2001) and Glaeser and Shapiro (2001), war-struck cities will only be rebuilt if the housing prices exceed the construction costs." Low demand for East German cities may again partially reflect the post-World War II exodus from east to west. Physical shocks become permanent population losses only if there is too little demand to locate in that place. For most cities over most of the past five centuries, demand for urban space has been robust enough to justify reconstruction.

While these bombing papers emphasize damage to physical capital in cities, Ciccone (2021) examines the loss of human capital in World War I in the state of Wurttemberg (Ciccone, 2021). Human capital is typically defined as the ability to produce (or fight) that is embedded in people, and so deaths pretty much always mean a loss of human capital. Yet the skills that enable valuable activity have changed dramatically over the centuries, which makes the measurement of human capital particularly fraught.

Fighting did not occur in Wurttemberg and so its cities were not destroyed and non-combatants generally survived, albeit on fewer calories. The war did, however, kill approximately three percent of Germany's pre-war population and that carnage occurred disproportionately among young males. Ciccone (2021) finds that Wurttemberg municipalities with more deaths had significantly less population in 1919, 1933 and even in 1960. The contrast between bombings and war deaths suggest that lost human capital may be more important than destroyed physical capital for city resilience. Fewer young adults may have meant fewer entrepreneurs to fuel new growth.

While these deaths appear to have had a long-lasting impact, Wurttemberg's cities, especially Stuttgart, enjoyed a great deal of success after the war. Populations rose almost everywhere, but they rose more in areas where fewer men had died during the war. The cities of Wurttemberg were resilient, even though the shock had an impact. 
Miguel and Roland (2011) examine the impact of American bombing on Vietnamese cities. They find essentially no long run impact of bombing on population density, poverty and many other outcomes. Feigenbaum, Lee and Mezzanotti (2017) examine the trail of Sherman's destructive march through the South during the US Civil War. While the march seems to have depressed land values in impacted areas for decades, the negative impact on manufacturing outcomes seems to have disappeared in fifteen years. We now turn to peacetime urban disasters.

\section{Earthquakes, Fires and Hurricanes}

The long run impact of earthquakes and floods is intrinsically harder to estimate than the impact of a nationwide bombing campaign. For example, Pereira (2009) describes the Lisbon earthquake of 1755 as "the largest natural catastrophe ever recorded in Europe." He is able to estimate a staggering direct cost of "between 32 and 48 percent of the Portuguese GDP" by looking at the records of destroyed structures, but how can we really know the longer-term impact? What other city, or set of cities, provides a really compelling counterfactual to compare with Lisbon?

Bairoch (1988) estimates that Lisbon's population increased from 185,000 in 1750 to 195,000 in 1800 and 240,000 in 1850. Lisbon's growth rate between 1750 and 1800 is slightly higher than the growth rates for Madrid and Amsterdam, which are both plausible comparands. Madrid's population then shoots past Lisbon's between 1800 and 1850, but the timing of that surge fits poorly with the earthquake. Pereira (2009) goes further and argues that the earthquake actually had positive economic effects in the medium run, possibly because the Marquis de Pombal's adept handling of the earthquake gave him enough political capital to implement reforms.

Schencking (2006) describes the great Tokyo earthquake of 1923 as "one of the most devasting and disruptive natural disasters of the $20^{\text {th }}$ century" that "killed more than 120,000 citizens, and rendered just over 1.5 million people homeless." Yet the population of the Tokyo prefecture rose from 3.70 million in 1920 to 4.49 million in 1925 to 7.35 million in 1940 (Tokyo Metropolitan Government, 2018). Not only did Tokyo survive the earthquake, but the city's population grew dramatically after the earthquake.

Aldrich (2012) examines the impact of the Tokyo earthquake at police precinct level on population growth between 1922 and 1933. He finds that the share of the population that was killed by the 
earthquake positively predicts population growth over the entire time period. That effect is statistically insignificant from zero, but there is no evidence that the earthquake had a negative impact in the neighborhoods where it did the most damage.

Ager et al. (2020) describe the 1906 San Francisco earthquake as "one of the worst natural disasters on American soil," in which "more than 225,000 people became homeless and 28,000 buildings were destroyed.” Yet San Francisco’s population increased from 343,000 to 417,000 between 1900 and 1910. The city's population growth rate was faster between 1900 and 1910 than it was between either 1890 and 1900 or 1910 and 1920. San Francisco grew faster during that decade than many of its coastal competitors, such as Boston and Philadelphia.

The earthquake impacted cities throughout northern California, and Ager et al. (2020) looks at the impact of earthquake intensity by comparing cities throughout the far west. They do find a negative impact of earthquake intensity, although this effect is concentrated on cities outside of the bay area. They find that the earthquake reduced the level of in-migration, which then echoed through the decades because of the process of chain-migration where old migrants attract new migrants. The loss of physical capital within the city seems to have done more harm than the loss of human capital outside of the city.

This paper can also be understood as telling us about the limits of "location fundamentals." The city of San Francisco, and much of the Bay Area, had those fundamentals and consequently the earthquake had little long run impact. Outlying areas spread throughout the vast American west are much more of a featureless plane. Random growth, which can come from chain migration, is much more likely in such an environment and hence a natural disaster can have long term consequences.

Tran and Wilson (2020) provide a particularly optimistic view of natural disasters in the US since 1980. They study local per capita income and find "an initial decline, followed by a recovery to a level of income per capital that is $0.6 \%$ above the baseline trend eight years after the disaster.” The post-disaster bounce back is "initially explained by a temporary boost in employment, especially in construction, as well as government support programs, including both direct disaster aid as well as automatic stabilizers like unemployment insurance and income maintenance programs.” The longer-term positive effects are more opaque, as are the positive effects that they detect of disasters 
on housing prices. Places may actually be building back better, and it certainly seems these disasters are not causing local ruin.

The population of both the city and metropolitan area of New Orleans declined sharply after Hurricane Katrina. The metropolitan area's population has largely recovered, but the city's population remains substantially below its level in 2005. Yet the population of the city of New Orleans has been falling since 1960, and much of the destroyed real estate has long been worth considerably less than the price of new construction (Glaeser and Gyourko, 2005). If a declining city's population is maintained primarily by its durable housing stock, then that city's population is quite likely to drop if that housing stock is destroyed.

Fires are also frequently found to provide long-term benefits for cities by clearing away the accreted rubble of centuries. The Great Fire of 1666 was “the worst fire in London's history,” during which "three-and-a-half days of wind-driven flames destroyed 85 percent of the City: some 13,200 houses, 52 company halls, 87 churches, plus St. Paul's Cathedral, the Royal Exchange, the Guildhall, and other venerable landmarks” (Tittler, 2001). Yet there is little evidence that this derailed London’s overall population growth.

The population of the compact City of London itself seems to have shrunk from 132,000 to 93,500 between 1650 and 1700, but over the same decades, the population of the greater London region expanded from 400,000 to 575,000 (Harding, 1990). By 1800, the population of the larger city climbed to almost one million, exceeding the population of any European city since Rome (Sheppard, 1998). While the combination of plague, fire and rebuilding does seem to have dispersed population from the city center, the overall metropolis expanded during the $18^{\text {th }}$ century, as Great Britain became more populous and its commerce continued to grow.

London widened its streets and reduced its reliance on hazardous building materials after the fire. It did not, however, follow the more radical paths to rebuilding imagined by Christopher Wren and John Evelyn. In other places, fires provided a tabula rasa that arguably generated longer term benefits for the affected city. Hornbeck and Keniston (2017) find that "the Boston Fire of 1872 created an opportunity for widespread simultaneous reconstruction initiating a virtuous circle in which building upgrades encouraged further upgrades of nearby buildings," and that "land values increased substantially among burned plots and nearby unburned plots, capitalizing economic gains comparable to the value of burned.” This remarkable finding suggests that the benefits of 
coordinated property improvement were sufficiently high to offset the lost property burned by the fire.

The Chicago Fire of 1871 "caused almost 200 million dollars in damage, left homeless nearly 100 thousand people, or about a third of the city’s population and virtually leveled 2,100 acres” (Pauly, 1984). Yet despite this destruction, the city's population continued to explode from under 300,000 in 1870 to over 500,000 in 1880. Since post ignem Chicago combined enormous demand for space with an absence of physical structures and empty land at its core, the city attracted a bevy of talented architects, including Dankmar Adler, Daniel Burnham, William LeBaron Jenney and Louis Sullivan. This agglomeration of talent both rebuilt the city, and invented the skyscraper, which would reshape city skylines worldwide, in the process.

\section{Plagues}

The Black Death, Yellow Fever, Cholera and the 1918-1919 Influenza Pandemic are the most direct antecedents of the COVID-19 pandemic. Yet there is little evidence that any of these terrible killers did much to deter urban growth, at least in the west, and at least since $1200 \mathrm{CE}$. The Great Plague of London directly preceded the great fire, and so the resilience of that city to the fire that was discussed above, also suggests the city’s resilience to the plague.

We have more quantitative evidence on the long-term evidence of the Black Death on urban fortunes. Jedwab, Johnson and Koyama (2019) examine the correlation between mortality during the 1347-1352 period and long-run city growth rates. Christakos et al. (2005) provide the death data for 274 cities, which they pull from a wide variety of historical sources. Bairoch (1988) is the ultimate source of the city population data; Jedwab, Johnson and Koyama (2019) use a updated variant of this standard source.

They estimate a coefficient of -.87 when regressing population growth between 1300 and 1400 on the Black Death mortality rate, which roughly means that for every 100 deaths, the population shrank by 87 over that century. At least initially, the loss was almost one-for-one. But the coefficient shrinks to -.28 when they used population growth between 1300 and 1500 as the dependent variable. This shift implies 59 of those lost people have been made up for by new migration or extra fertility or lower mortality. When they regress population growth between 1300 
and 1600 on Black Death mortality, they estimate a positive coefficient, which suggests that all of the adverse population effects had been complete offset by that time period. This fact does not mean that those cities were unchanged by the experience, or that Europe as a whole was not less populous than it would have been without the demographic catastrophe, but just that the plague experiences of individual cities had ceased to determine their population levels. ${ }^{3}$

The experience of the Black Death does not suggest that cities quickly shrug off plagues. The 200 or so years needed to undo the demographic losses from the pandemic suggest a very long halflife for this disaster. Moreover, thousands of villages were deserted during the medieval era, and many of those were probably victims of the Black Death. The more far-reaching impact of the plague again suggests that human, rather than physical, capital is the key determinant of long run urban success. Needless to say, COVID-19 has not yet had a remotely comparable impact on the human capital of any city.

The Black Death had other consequences, some of which ended up helping cities in other ways. The labor shortage that followed the plague led to high wages, which in turn led to an increase in demand for the luxury goods, which were primarily produced in cities. Indeed, the de-urbanizing pandemic that emptied the cities of the $14^{\text {th }}$ century may have helped to enrich and expand the cities of the $15^{\text {th }}$ century.

Despite a steady stream of urban epidemics, urbanization became a defining feature of the $19^{\text {th }}$ century in Europe and the US. Chippaux and Chippaux (2018) write that it is "likely that the first American cases [of Yellow Fever] resulted from an introduction of the YF virus by the crews of Columbus between 1492 and 1495 coming from the Canary Islands.” Between 1793 and 1822, thousands died in America's coastal cities from the mosquito-born illness. While large numbers of wealthier people would evacuate Philadelphia and New York during outbreaks, these cities continued to grow nonetheless. Between 1790 and 1830, Philadelphia's population grew by 180 percent and New York's population almost quintupled.

\footnotetext{
${ }^{3}$ Jedwab, Johnson and Koyama (2019) also instrument for plague severity, by using the delay between 1347 and the onset of plague in that city. The cities that had a few more months or years before the plague began also experienced lower levels of mortality from the plague. This instrument should reduce biases from measurement error, and the estimated coefficients are broadly similar.
} 
Cholera emerged in the Ganges delta in 1817 and made its way by land and sea to cities of Europe and North America by the 1830s. Death rates were typically far higher than from COVID-19 in 2020. Rosenberg (2009) describes the experience of American cities, such as New York, during the "cholera years." Just as with Yellow Fever before and COVID-19 since, cholera brought forth a temporary urban exodus of more prosperous people fleeing before the disease.

Yet there is little evidence that cholera shut down urban growth either in the U.S. or in Europe. Instead, cities began to grow and to defend themselves against the disease. That fight began before there was any robust medical knowledge of the sources of epidemic diseases. "Miasma" theory credited noxious air for cholera and Yellow Fever rather than mosquitoes and tainted water, but that erroneous belief led to highly beneficial investments, like water systems, to reduce the swampy character of many cities.

Philadelphia began its pioneering water system investments in the 1790s, directly in response to Yellow Fever outbreak. New York's Croton Aqueduct (and Central Park) were built partially in response to Cholera. After 1854, when the pattern of cholera cases in London taught Dr. John Snow the disease's secret, the case for water-related infrastructure became even clearer. Cities also invented new institutions, such as New York's Metropolitan Board of Health, which reduced the “last-mile problem” by fining tenement owners who didn't connect to the water and sewer system. It took many decades and vast sums of money, but the $19^{\text {th }}$ century was an age of robust urban resilience as cities grew, despite terrible diseases, developing the tools to fight those diseases.

The 1918-1919 Influenza Pandemic was the most direct precursor to the COVID-19 pandemic. As the US urbanization rate grew from 51 percent in 1920 to 56 percent in 1930, it seems obvious that the pandemic did not slow down urbanization. Velde (2020) finds the pandemic produced a clear but short economic downturn across the US as whole. Brainerd and Siegler (2003) find that states with a higher death rate actually experienced faster subsequent income growth.

Fluegge (2021), however, provides the most negative assessment of the longer-term impact of pandemic of urban trajectories. Across a sample of 42 cities, he finds that influenza deaths have a significant negative correlation with population in 2010. Cities with more rain in September 1918 experience more influenza death during that year, presumably because people stayed inside, and excess rain during that month also predicts less population today. 
Fluegge (2021) and Ciccone (2021) both provide suggestive evidence that the destruction of human capital can adversely impact a city's growth over a 100-year period. Human capital, at least as measured by formal education, seems to have become more important for urban fortunes during the late $20^{\text {th }}$ century. It is possible that shocks to human capital will be even more important going forward, but future research will need to test that hypothesis. Both of these studies examined shocks that occurred at the same time period.

Moreover, the mechanism driving the effects they identify is unclear. Perhaps the deaths led to less local entrepreneurship or to less construction during the heady days of the early 1920s. Yet a modest long-run impact on population does not reject the general notion that cities have largely been resilient to health shocks, as well as earthquakes and bombing. These human capital shocks led to less population growth, not population decline. We now turn to the widely accepted claim that cities are quite vulnerable to economic and political shocks.

\section{Urban Vulnerability to Economic and Political Shocks}

In the previous section, I argued that shocks that destroy structures, or even shocks that kill people, have only a modest impact on urban fortunes. If the location retains its positive attributes, then there will be new building and people will move back or replace the dead. Here I note that cities are quite vulnerable to shocks that reduce economic vitality or political strength. This claim requires little empirical support as there have now been literally hundreds of studies using the "Bartik" instrument (e.g., Diamond, 2015), in which local population and employment is found to move closely with national changes in its dominant industries.

Given the size of this literature, there is little need to go through numerous examples to show the power of economic shocks in shaping urban fortunes. Consequently, I will instead use this section to make two points. First, political shocks were more important than economic shocks for large cities before the $19^{\text {th }}$ century, because major cities were large because of their political importance. I will then focus on the massive deindustrialization shock that hit wealthy world cities in the late $20^{\text {th }}$ century, with a subsection on the aspects of this shock that made it particularly terrible in some 
places and a subsection on the urban features that protected against the ravages of deindustrialization.

\section{Political Shocks}

The world has had cities with populations close to one million for at least 2,000 years, yet until 1800, every one of those cities - from Chang'an to Baghdad - was the capital of a mighty state. The wealth of those cities, like the wealth of Rome itself, reflected the ability of their government to extract resources from far-flung subject areas. Ades and Glaeser (1995) discuss how the growth spurts of these cities, including Edo under the Tokugawa Shogunate and Tudor London, coincided with an increasingly centralized government that distributed resources to people who were physically proximate. Those resources quelled the local discontent that can destabilize a regime.

Yet there are also negative political shocks that lead to urban decline. As the western Roman Empire disintegrated, the capital of that empire was moved from Rome itself to Milan. As Rome lost its political power, its population shrunk from approximately 1,000,000 people to perhaps as few as 5,000 (Hodges, 1993). Unlike many ancient cities, Rome would have a second and third act because it housed the Papacy, which can also be seen as a political advantage that rose in importance over the centuries. Rome then became the capital of Italy after its $19^{\text {th }}$ Century reunification and expanded again.

Chang'an may have been the largest city in the world during its Tang Dynasty heyday, perhaps with one million inhabitants. At the end of that dynasty, the city was sacked, and the capital was relocated. Like Rome, Chang'an shrank dramatically after it lost political power. Angor Wat and Ayutthaya were once large capitals of important Asian states. After the collapse of their polities, they both became spectacular ruins.

The loss of political power in the $20^{\text {th }}$ century is far more likely to lead to a decline in relative population rather than wholesale collapse. St. Petersburg was the capital of the Russian Empire in 1900 and its population was 28 percent higher than the population of Moscow. In 1975, after fifty years as capital of the U.S.S.R., Moscow had twice the population of the old capital, which had changed its name to Leningrad. In 1950, when Rio de Janeiro was still the capital of Brazil, its 
population was larger than the population of Sao Paulo. Today, sixty years after Brasilia became Brazil's capital, Sao Paulo also has about twice the population of its erstwhile urban rival. ${ }^{4}$

The survival and continuing growth of cities like Rio and Petrograd reflects the fact that $20^{\text {th }}$ century capitals could lose their status without being conquered and sacked. Consequently, the housing stock and physical assets of Imperial St. Petersburg remained and help to anchor the city. Moreover, capital cities now do far more than just political administration. Rio de Janeiro was a center of culture and commerce, as well as a capital, which explains why it continued to grow after 1960.

Why were late $20^{\text {th }}$ century economics shocks particularly painful?

Before 1800, there were certainly commercial cities that sat on trade routes that lost importance and population when their trade routes were abandoned. The Silk Road that connected China with Europe first declined after the fall of the Tang Dynasty in 907, and then again after European merchants discovered the sea route to China. The cities that had flourished along this route, such as Balkh and Kashgar, suffered with the decline in travel along that route. Chandler and Fox (2013) estimate that Kashgar's population declined from over 50,000 in the $16^{\text {th }}$ century to under 20,000 by the late $18^{\text {th }}$ century.

After experiencing an urbanization explosion during the $16^{\text {th }}$ and $17^{\text {th }}$ centuries, the Dutch urbanization rate actually declined in the $18^{\text {th }}$ century (Van de Woude, 2020). The manufacturing center of Leiden particularly suffered, losing more than one-half of its population between 1700 and 1800. Amsterdam was still able to survive as a hub of global commerce, but Leiden lost its role as a major center for manufacturing textiles. High wages, mercantilist policies among its competitors, and British access to both raw materials and new technologies eroded the comparative advantage of the Dutch industrial city (Wilson, 1939).

Yet when the industrial revolution got started and powered the great urban boom that lasted from 1800 to 1930 , the overall pace of urbanization was so fast that economic shocks were rarely large

\footnotetext{
${ }^{4}$ Bonn's population moved little either during its years as capital of West Germany or when it lost its capital status, presumably reflecting both the highly federalized nature of German government and the relative stability of the German urban hierarchy. By contrast, Berlin expanded enormously when it became the capital of a united German Empire in the $19^{\text {th }}$ century.
} 
enough to significantly reduce urban populations. None of the 30 largest cities in the US in 1900 had fewer residents in 1930. According to Chandler and Fox (2013), none of Europe’s larger cities in 1900 had lost population in 1925 and only one (Berlin) would lose population between 1925 and 1950. For most of the past 200 years, massive urbanization meant that city populations grew even if a city's economy lost ground relative to its competitors. Consequently, downturns only meant adjusting to slower growth not to the downsizing of city populations altogether.

Yet since 1930, and especially since 1950, city populations have regularly shrunk. Indeed, out of the 10 largest American cities in 1950, eight of them have less population today. Three of them (Cleveland, Detroit and St. Louis) have lost more than one-half of their population levels. Between 1931 and 2001, both Liverpool and Glasgow lost more than 45 percent of their populations. These population declines have been associated with both suburbanization, which kept the size of the greater metropolitan regions constant, and movement away from the metropolitan area as a whole. The metropolitan areas that surround Cleveland, Detroit and St. Louis added people between 1960 and 2010, but they shrank relative to the US as a whole and their per capita personal incomes are below America’s metropolitan average. Glaeser, Scheinkman and Shleifer (1995) find that the negative impact of manufacturing concentration in 1960 on subsequent employment is actually larger for metropolitan areas as a whole than for central cities.

In many cases, urban deindustrialization has been associated with terrible consequences for their affected cities and their inhabitants. Crime rates spiraled upward in many of these places between 1960 and 1990. Cities lurched to the edge of bankruptcy. Families got locked into multigenerational poverty traps. Why were these economic shocks so disastrous for many western cities, especially in the United States?

The first reason why the economic shocks of the 1960s and 1970s were so difficult for western cities is that those shocks were accompanied by, and often caused by, improvements in transportation technology. Railroads and waterways had provided a comparative advantage for older manufacturing cities, which largely disappeared in the age of the highway and the container ship, which abetted production in lower cost locales. Yet those highways also made it easier for ordinary people to leave older, colder cities for the suburbs and the sunbelt. Cities will always face particular risk anytime there is a combination of economic shocks and easier exit. 
Exit risks are - again - particularly acute in the US because America has so many, varied metropolitan options and because physical distances are so large and cultural differences have been attenuated since the end of the Jim Crow South. The climate is not particularly different between London and Manchester. Miami and Minneapolis are further apart than Rome and Stockholm, and have even more extreme differences in their temperatures. Yet while Miami and Minneapolis may have totally different climates, they are culturally quite similar. Migrants who move within the Schengen Area, however, will often need to speak new languages and adapt to new legal regimes.

Large spatial distances in the US also limit the ability of declining cities to provide extra "space" for people and businesses in thriving cities. Birmingham is a 90-minute train trip from London, which means that its cheaper office space can lure some back-office functions from the crowded metropolis. Buffalo, NY, is a six-hour car trip from New York City, and there is a vast amount of inexpensive land that is far closer to Manhattan.

The second reason why deindustrialization was so problematic is that manufacturing firms had relied on workers with highly specialized, not general, knowledge. Ford's assembly lines thrived by utilizing Adam Smith’s principle of the division of labor. Their workers didn’t need to know about many things, and America's automobile plants offered high wages to high school dropouts. When the factory jobs disappeared, the workers had few alternatives, and few employers were interested in taking advantage of this narrowly specialized (and highly unionized) labor pool.

A third reason - that is more particular to the US-is that fiscal decentralization meant that economic decline led to a decline in the level and quality of public services. In 1975, New York City teetered on the edge of bankruptcy. Chicago couldn’t plow its streets during a massive 1979 blizzard. Washington, D.C., despite the advantages of being a national capital, was unable to control its murderous streets. Urban schools looked like a poor substitute for schools in more prosperous suburbs, and the children who went to those schools ended up far poorer than their suburban counterparts (Glaeser, 2020).

The urban public service gap further encouraged the rich to leave cities like Detroit and St. Louis. This force was generally weaker in countries, where national governments take responsibility for services, including schooling and police, that are largely local in the US. Moreover, many older European cities, including London and Paris, have amenities that have accrued over centuries that serve to anchor their wealthy populations in place. 
In the US, urban flight was compounded by the ethnic antagonisms - and outright racism - that have been regular parts of urban life and urban politics. The existence of neighborhood "tipping points” discussed by Grodzins (1956), formalized by Schelling (1971) and empirically documented by Card, Mas and Rothstein (2008), implies that a neighborhood can quickly change its racial composition. As racial change fueled white fears, white voters first elected former law enforcement mayors, like Detroit’s Roman Griggs or Philadelphia’s Frank Rizzo, who often seemed unconcerned with the civil rights of African Americans. As whites became a voting minority, these mayors were replaced by African Americans, like Coleman Young. In 1980, a poll found that seventy percent of Detroit's white residents agreed that "Even since blacks became the majority in Detroit white people are often discriminated against here” (Glaeser and Shleifer, 2005). Even if they were baseless, these views may have been one reason for the white outmigration that occurred. Given the association between income and race, when cities, like Detroit, became majority-minority in the 1970s, their relative incomes typically declined even further, which created even more challenges for funding local services.

America's industrial heartland, with difficult weather, racial divisions and relatively few college graduates, proved particularly vulnerable to an economic shock that was accompanied by a reduction in mobility costs. Continental Europe was far more robust. I now turn to the factors that explain resilience in the face of urban deindustrialization.

\section{Urban Reinvention and Stability from Stuttgart to Seattle}

Manufacturing declined in cities throughout the globe, but in many places, that decline was followed by reinvention. In the US, that reinvention typically came in the form of new industries and new companies. The New England Confectionary Company's former Cambridge factory is now leased by the Swiss pharmaceutical company Novartis. Some European companies, however, reinvented themselves from within. Mercedes-Benz, Bosch, and Porsche are still dominant companies in Stuttgart, as they were fifty years ago, but their local labor force has become increasingly oriented towards research and development. Stuttgart is the European leader in patenting activity (Fuchs and Wasserman, 2005). Five different factors are associated with urban

reinvention in the west: political capitals, schools and universities, attractive local amenities, the 
presence of capable corporations who have chosen not to relocate, and legal regimes that favor business formation and relocation.

The most obvious source of stability is a large, long-standing political capital. Both London and Paris suffered significant industrial decline, like New York City, but no one feared that those cities were headed for the trash heap of history. Most directly, national governments generate significant employment that remain when the factories shut. More indirectly, the local presence of the nation's leaders ensures that a capital's social and fiscal problems will be fought with the resources of the nation. When President Ford told New York City to sort out its own finances ("Ford to City: Drop Dead” roared the headline), President Pompidou commissioned a grand new museum for Paris. Moreover, long-standing capitals, like London and Paris, further benefit from monuments, parks and museums built over centuries, which serve to both attract tourists and wealthy residents.

In 1971, a billboard rose asking "Will the Last Person to Leave Seattle Please Turn Off the Lights," because Boeing, Seattle’s major employer, had shrunk its labor force. Fifty years later, Boeing still remains and a whole new generation of employers, including Microsoft, Amazon, and Starbucks, have remade the city. The city's long-standing commitment to education, which partially reflects the priorities of Boeing's engineering-oriented labor force, helps explain why these new firms are in Seattle. In some cases, like Microsoft's Bill Gates, the education system of Seattle directly produced an extraordinarily successful technology entrepreneur. In other cases, like the location decision of Amazon's Jeff Bezos, companies were lured by the abundance of talent in the city. Education also played a role in the location of Starbuck's first store and eventual headquarters, because the willingness to spend on expensive coffee products is also correlated with years of schooling.

An abundance of studies documents the correlation between education and urban success both in the US and elsewhere (Glaeser, Scheinkman, and Shleifer, 1995, Shapiro, 2006, Chauvin et al., 2016). Moreover, education appears to have been particularly valuable in cities that had been oriented towards manufacturing (Glaeser, Gyourko, and Saiz, 2006), perhaps because general human capital enables reinvention. The presence of land grant colleges in the US, which were founded with national government support before 1940 predicts urban success in late $20^{\text {th }}$ century America (Moretti, 2004). One major difference between Stuttgart and Detroit is that Stuttgart has 
a far greater presence of schools, universities and publicly funded research institutions, such as the University of Stuttgart and two Max Planck Institutes.

Brueckner, Thisse and Zenou (1999) asked "Why is central Paris rich and downtown Detroit poor?” They answered the question by emphasizing that downtown Paris is packed with amenities from the river Seine to the Louvre to the boulevards planned by Baron Haussman in the $19^{\text {th }}$ century. Downtown Detroit has far fewer urban assets and suffers from high crime rates. The amenities of Paris, which in turn reflect its millennium long role as one of Europe's leading capitals, power an enormous tourism industry and help attract high human capital individuals to live in the city. The Parisian amenities are largely man-made, but the weather of coastal California has been an enormous source of resilience for Los Angeles, San Diego and the San Francisco Bay area. An increasingly wealthy and footloose world is increasingly willing to relocate to places that offer a higher quality of life.

One of the unfortunate consequences of industrial strength is the legacy of sometimes unattractive industrial buildings and pollution. Cleveland's Cuyahoga River burned regularly because of the waste in its waters. Consequently, non-industrial cities, like Edinburgh, have often proved more resilient over industrial cities, like Glasgow. Whereas the harbors that anchored older commercial cities can be turned into an attractive urban playground, the massive factories that mark the later industrial cities are hard to make appealing.

Stuttgart deserves the soubriquet "birthplace of the automobile" far more than Detroit, and yet Stuttgart has survived deindustrialization far better than its American rival. One difference may be that the German companies that anchor Stuttgart-Daimler and Porsche- occupied the luxury end of the market that proved more resilient to competition from Japan and Korea. Bosch, which is the largest of the Stuttgart car-related companies, supplies parts for so many of the world's automobile producers that its employees occasionally claim, "no car without Bosch.”

Bosch is more of a technology company than a traditional car company, which also helps explain why Stuttgart remains vibrant. Seattle’s arc from manufacturing hub to technology center occurred because new firms, like Microsoft, appeared and replaced the production jobs lost when Boeing downsized. Stuttgart's arc from manufacturing hub to technology center occurred within Bosch and Daimler themselves. But these firms also didn't choose to relocate to a cheaper, more businessfriendly location, partially because that would require leaving Germany and partially because 
Bosch is also owned by a charitable foundation, which means fewer shareholders demanding that the firm relocate somewhere with lower wages. German companies who relocate for lower wages risk damaging the relationships both unions and government.

Within the US, the logic of shareholder value pushed firms to locate to places where labor was less expensive, and that particularly meant moving to states that had passed "right-to-work" laws that made union organizing more difficult (Holmes, 1998). Sir Peter Hall’s initial vision of “enterprise zones" was motivated by the success of business-friendly regimes in Hong Kong, Korea, Singapore and Taiwan (Hall, 1991). He wanted "to try to recreate, in selected areas of British cities, the same spirit of unbridled enterprise that has characterized those economies," by introducing "maximum freedom and minimum restriction."

Britain's Enterprise Zones and America's Empowerment Zones have featured subsidies more than regulatory relief, but there are places where simpler regulation or pro-business policies seem to have been effective at aiding resilience. When a military base at Fort Devens, MA, was closed, the governor created a Devens Enterprise Commission that enabled one-stop permitting for businesses that wanted to locate within the Devens area. As of May 2021, a bevy of businesses have located in the area and the two nearest towns (Ayers and Shirley) have unemployment rates that are lower than the state average.

The durability of Columbus, Ohio, relative to either Cleveland or Cincinnati is overdetermined. The city is a state capital that houses a major research university (Ohio State) and has little legacy of heavy industry. Yet the city's privately funded Columbus Partnership has long ensured that it has a pro-business environment that is more common in Georgia than in Ohio. The pro-business attitude of Columbus is more typical of the American sunbelt than either coastal America or older industrial cities.

While some cities have survived deindustrialization better than others, almost all industrial cities have suffered scars from the downsizing of manufacturing. By contrast, in the previous section, we emphasized cities' remarkable resilience in the face of natural disasters that destroy physical capital (fires) or humans (plagues). Yet there are also a small number of physical disasters that have caused massive harm to individual cities and even derailed urban civilizations. We turn to those next. 


\section{Four Outliers: Physical Disasters with Lasting Consequences}

While section II paints a relatively rosy picture of urban survival from physical shocks, this section highlights cases in which physical shocks seem to have had massive, long run consequences. Since these are individual cases studies, I have no means of proving causality. Yet in each case, there are good reasons to believe that the physical catastrophe played a significant rule in the reversal of fortune that followed.

The Plague of Athens, 430 B.C.E.

Few cities have ever glittered so brightly, especially in our collective memory than fifth century Athens. Chains of creativity generated breakthroughs in history (Herodotus, Thucydides), drama (Aeschylus, Euripides and Sophocles), philosophy (Anaxagoras, Democritus, Socrates), sculpture (Phidias, Myron), medicine (Hippocrates) and democracy itself (Pericles). Yet the city's political, commercial and military success brought it into direct conflict with the older, land-based power of Sparta. Pericles led the Athenians into war, arguing that the superior Athenian fleet "could harass the coastal states of the Peloponnesus with relative impunity,” while the people of Athens sheltered behind the city’s walls “which are just as strong as anything they could build” (Thucydides, 1974).

Pericles was correct that the Spartan warriors would not breach the city's walls, but those walls could not keep out the plague. Athens, like modern cities, was a node on the world's transportation and travel network, and plague entered through its port of Piraeus. Thucydides thought that Ethiopia was the ultimate source of the illness. Modern experts believe that Asia is a more likely place of origin, but there is no consensus on the actual disease involved. The one clear fact is that it ravaged through the densely packed city.

Thucydides (1974) writes that the plague "carried away all alike, even those who were treated and dieted with the greatest care.” The sickness killed Pericles and his sons. The city was packed with refugees who fled before the Spartan Hoplites, and they were particularly vulnerable to the illness because "there were no houses for them, and, living as they did during the hot season in badly 
ventilated huts, they died like flies." Modern scientists estimate that over "the next 3 years, most of the population was infected, and perhaps as many as 75,000 to 100,000 people, $25 \%$ of the city's population died" (Littman, 2009).

From one viewpoint, Athens stands as one of history's most resilient cities. For 25 more years it soldiered on again Sparta until finally losing the Peloponnesian war. The city produced many great cultural works after the plague, including the plays of Aristophanes, the philosophic writings of both Plato and Aristotle and the sculpture of Praxiteles. It would remain an intellectual center during the Roman Empire and its Byzantine successor and would become the capital of an independent Greece in the $19^{\text {th }}$ century.

Yet before the plague, Athens had been the dominant city in the western world. After the plague, it was not. Given that Athens held out against Sparta for a quarter century after the plague, it is at least plausible that Athens would have avoided defeat if its population was 33 percent larger. After the plague, Athens occupied a place in the Roman hierarchy much like Oxford or Cambridge in the $19^{\text {th }}$ century, which is far different from the London-like position it occupied before the plague. Consequently, it is reasonable to claim that plague really did significantly alter the fate of Athens for the worse.

Why did plague matter more for Athens in 430 BC than for London or Florence in the $14^{\text {th }}$ centuries? The $14^{\text {th }}$ century Black Death did little to influence the political hierarchy of cities. The Athenian plague had large political repercussions for that city, because the hierarchy of cities was highly unstable in 430 BC. Both Sparta and Athens believed that success in the war was important for the future of their polities. By the $14^{\text {th }}$ century, Europe had long specialized in defensive weapons of war, such as castles and armor, and so small groups of survivors from disease could still defend existing walls against marauders.

The Plague of Athens suggests that physical disasters can have a larger impact when they lead to political changes, which in turn reflect the stability and strength of the pre-disaster political system. Pre-disaster public capacity also helps to determine the death toll from the disaster itself. Kahn (2005) examines death tolls across 73 countries from 1980 to 2002 and finds that "democracies and nations with higher-quality institutions suffer less death from natural disaster." Even the most conservative estimate is that the death toll from Haiti's 2010 earthquake was more than 46,000, while the government's official figure was 316,000 (O’Connor, 2012). The larger earthquake, and 
associated tsunami, that struck Chile during the same year killed around 500 (Lindell, 2010). In the penultimate section of this paper, we will discuss the political stability and capacity of cities before COVID-19, and whether this shock is likely to lead to significant, detrimental changes.

\section{The Late Classic Plagues of the Antonines, Cyprian and Justinian}

Plague seems to have played a relatively minor role in the fate of the Mediterranean world for 500 years after the plague of Athens. Edward Gibbon famously wrote that "If a man were called to fix the period in the history of the world, during which the condition of the human race was most happy and prosperous, he would, without hesitation, name that which elapsed from the death of Domitian to the accession of Commodus.” Although Gibbon himself did not give the plague much credit for changing that state of affairs, more recent authors (e.g. LoCascio, 1991) have argued that the plague was significantly responsible for the so called "Crisis of the Third Century."

The first major disease outbreak began in Mesopotamia 165 or 166 CE, which is thought by many to be either Smallpox or the Measles, occurred in Mesopotamia. Littman and Littman (1973) argue that "a mortality rate of 7 to 10 percent would be a reasonable figure.” Other estimates have ranged as far as 50 percent or as low as 1 percent. The disease raged for 15 years and may have been responsible for another round of deaths in $189 \mathrm{CE}$.

Did these deaths contribute to Rome's decline? Sabbatani and Fiorino (2009) argue that depopulation due to plague made it increasingly difficult for Rome to defend its borders. Coemperor Lucius Verus' death from the disease made it easier for Aurelius to select his son Commodus as his successor, which itself proved to be destabilizing. If the disease mattered, it mattered because it changed the political equilibrium.

Yet the third-century crisis didn't really begin until 235 CE, fifty-five years after the Antonine Plague had essentially ended, so any causal connection is hard to confirm. The second plague, associated with Cyprian, a Carthaginian Bishop and Saint, ran from 249 to $262 \mathrm{CE}$, after the crisis had already begun. If anything, the Cyprian Plague's nature and mortality rate are even murkier than the nature and mortality of the Antonine Plague. 
Harper (2015) argues that "while the recovery from the Antonine plague proved the resilience of the system," the later "plague of Cyprian pushed the imperial machine beyond a certain threshold, and with the cascading change a new equilibrium had to be found.” The Cyprian Plague further reduced the empire's demographic resources, weakening its ability to fight against its external foes, like the Sassanid Empire which captured the Emperor Valerian in 260 CE. Harper (2015) makes this plausible claim, despite the fact that the plague's "demographic scale must remain unknowable.” The Empire was already in crisis from military defeat and the related assassination of Severus Alexander.

Diocletian would eventually reunify the empire and bring stability after $285 \mathrm{CE}$, but the urban hierarchy had been changed by the crisis. Diocletian himself ruled from Nicomedia in the East, and his successor Constantine, would move the empire's center of gravity to Constantinople, where it would remain for another millennium. Their western representatives were centered in Milan, not Rome, to be closer to the dangerous frontier. The third century crisis seems to have also changed urban form itself, as cities increasingly contained themselves within walls for protection from marauders.

The third - and certainly most devastating - late classical plague is the Plague of Justinian which came to Constantinople in $541 \mathrm{CE}$. Wagner et al. (2014) "sequenced and analysed draft genomes of $Y$ pestis obtained from two individuals who died in the first pandemic," proving that the illness was the Black Death. Mordechai et al (2019) do battle with the "consensus maximalist position" which claims that this plague "reduced the population of the late antique Mediterranean and Europe by more than a third, killing tens of millions and ending antiquity." The evidence for some of these claims is indeed tenuous, but Mordechai et al.'s (2019) own evidence still shows a dramatic decline in many of their indicators, including Latin inscriptions, epigraphs, and new legislation after 540 CE.

The Eastern Roman Empire did continue to function during this time period, but that does not disprove the hypothesis that this plague had a massive impact on Europe and its cities. The maximalist view emphasizes the political consequences of the plague, which may have prevented Justinian and his warlord Belisarius from reconquering Rome and reimposing the Pax Romana on the Mediterranean world. Considerably smaller populations of both the Roman and Sassanid Empires may have left both empires too weak to face the wave of Arab conquest that followed. 
The view that two centuries of Black Death played a major role in ushing in eight centuries of post-Roman poverty, warfare and largely rural life remains quite tenable, even though the evidence for this view is far from overwhelming.

\section{Minor Medieval Catastrophes at Dunwich and Bruges}

The claim that a succession of plagues led to the greatest deurbanizing event in western history is one of the grandest of hypotheses. The view that Dunwich never recovered from its fall into the sea is on a far tinier scale and leaves far less room for debate. In $1250 \mathrm{CE}$, Dunwich was a thriving and important East Anglian port and royal harbor, with over 5,000 inhabitants (Comfort, 1994). It stretched one mile along the coast, and seems to have been comparable in physical size to London. By the end of the $14^{\text {th }}$ century, the town appears to have had fewer than 1,000 inhabitants (Pye and Blott, 2006). Today, it has fewer than 150 residents.

The decline of Dunwich is no mystery. The town fell into the sea. Coastal erosion and aseries of impressive storms from 1287 onward destroyed physical structures and led to the "blockage and diversion of the harbour entrance” (Pye and Blott, 2006). A physical disaster can permanently mar a city's future if it also eliminates that city's economic raison d'être, which in Dunwich's case, was its harbor.

The case of Bruges is both considerably more significant and more ambiguous. Four facts are reasonably clear: (1) Bruges was an extraordinarily successful commercial city for three centuries, (2) "Bruges owed its 13th to 16th century wealth to the Zwin, an inlet that connected it directly to the North Sea," and (3) the "silting of the Zwin," from the $13^{\text {th }}$ to the $16^{\text {th }}$ centuries meant that "the toll sounded for [the ports of] Damme and Bruges at the time, and Antwerp took up their trade” (Charlier, 2011) and (4) Bruges' population declined from 125,000 in 1400 to 35,000 in 1500 (Bairoch, 1988). Bruges importance as a port and city was largely due to a storm in $1134 \mathrm{CE}$, which brought the Zwin quite near to the city, and when the Zwin subsequently lost its utility as a waterway, Bruges lost economic vitality.

The ambiguous part of this story is that Bruges's population then stabilized at 35,000 and eventually began to grow again. It eventually even regained a harbor, and the Zwin became a pleasant nature preserve (Charlier, 2011). The city remained viable - if at a vastly smaller and less 
significant scale-because the physical legacy of its golden age is so spectacular. It remains a tourist hub today, largely because of its marvelous art and architecture. As the city's investments gave it enduring values, it would have taken two physical shocks, both the silting of the Zwin and the destruction of the city’s structures, to have truly destroyed Bruges.

\section{American Race Riots during the 1960s}

Riots are an ancient urban phenomenon that occur when the number of disorderly individuals becomes so large that the probability of legal punishment for any one of them becomes arbitrarily small (DiPasquale and Glaeser, 1997). For example, during New York City’s 1863 Draft Riot, the deadliest such event in American history, Major-General John Wool declared "Martial law ought to be proclaimed, but I have not a sufficient force to enforce it” (Hernon, 2019). During the $20^{\text {th }}$ century, American riots were overwhelmingly associated with racial conflict, as Indian riots were linked to religious conflict. Before the 1960s, riots typically took the form of white aggressors targeting African Americans, as in the Atlanta Riot of 1905, the Chicago Riot of 1919 and the Detroit Riot of 1943. However, African Americans typically took to the streets during the riots of the 1960s, although the eventual victims were often also African Americans.

William Collins and Robert Margo have investigated the longer-term impact of these riots on earnings, employment and property values at the city level. ${ }^{5}$ They find that property values grew less in both neighborhoods and cities that experienced severe riots during the 1960s (Collins and Margo, 2007). This effect persists when they use summer temperatures as an instrument for the presence of a severe riot. The earnings of African Americans and the share of African American men who were employed in 1980 were also lower in cities that experienced severe riots. Surprisingly, the effect of riots during the 1960s seems to influence wage growth from 1960 to 1970 less than wage growth from 1970 to 1980, suggesting that the impact of the riot had snowballed over time.

Why did the riots have a longer-term impact on cities? If the riots only destroyed some physical property, presumably that property could have been rebuilt relatively swiftly as after a standard

\footnotetext{
${ }^{5}$ They focus on central cities, not metropolitan areas, and there is little evidence to suggest that riots did serious harm to the longer-term fortunes of these larger geographic units.
} 
physical disaster. Yet the riots seem to have either caused, or been correlated with, a larger political shift at the city level.

Detroit's immediate political reaction to its riot was to elect Roman Gribbs, a sheriff and law-and order candidate who appealed to a white population that feared more unrest. Yet the white share of the city's population continued to decline, and four years later, the city elected Coleman Young, a long-term champion of African American riots who seemed radical to many whites. Whites continued to leave the city and the region, and jobs disappeared for African Americans.

Riots are political events, not random acts of nature. They generated fear, especially in the white community, who found it quite easy to relocate thanks to highways and suburbs. The initial process of white exodus then changed the political equilibrium so that some cities elected leaders who whites found less congenial and out-migration continued. Detroit was wealthy in 1960, but by 1990 its name had become synonymous with poverty. The city’s homes were valued for far less than the cost of building new structures (Glaeser and Gyourko, 2005). Just as in the case of East Germany after WWII bombing, physical destruction is far more likely to leave a permanent footprint when prices are so low that private developers will not pay to rebuild.

One lesson of the riots is similar to the lesson of the late classical plagues: disasters have longlasting consequences when they change the prevailing political equilibrium in a significant fashion. A second lesson is that the impact of disasters can be larger when real estate prices are low, because there is less incentive to rebuild homes and offices and because property vacancies become a real possibility. We now apply these lessons to the aftermath of the COVID-19 pandemic.

\section{Urban Vulnerability Post-COVID-19}

As I write this words in September of 2021, the COVID-19 pandemic continues, yet it is possible to hopefully look towards a post-COVID future. It remains possible that COVID-19 will mutate into something deadlier and even more virulent. It remains possible a new pandemic will emerge in the next few years. I do not expect such disastrous events to occur but if they do, the urban world will be at significant risk. In this subsection, however, I assume that COVID-19 will eventually come under control and that there will be no new pandemic anytime soon. I start by 
noting that many American cities have faced the pandemic with far less resilience than they had when facing the terrorist attacks of 2001.

There are many factors which make cities today more resilient. We have a near-miraculous ability to identify diseases and concoct vaccines. We have an information super-highway to transmit data and a vast number of well-educated citizens. I do not want these, and many other urban strengths to be missed. Moreover, the larger lesson of history is that cities have largely proved resilient. I expect that resilience to continue, despite the vulnerabilities that are chronicled in this section.

The past three sections have tried to be global or at least trans-Atlantic, but this section is overwhelmingly US-centric. I narrow my focus, not because I believe that the US is more important than elsewhere, but because of the limits of my knowledge. I hope that international scholars will continue to study and hopefully improve urban resilience around the world.

\section{The Pre-existing Weaknesses of Cities}

Many of the larger and better educated cities of the west, including New York, London and San Francisco, experienced economic revivals starting in the 1980s. Finance and technology firms thrived in the dense confines of these older cities, partially because of the easy flow of knowledge. Regulatory reforms, such as London's Big Bang, enabled the growth of the modern financial services industry. Yet these cities' very successes also created conflicts and discontent, partially because the success of these industries did not flow equally throughout the city, and partially because the public sector failed to deliver opportunity to poorer urbanites (Glaeser, 2021).

Early $20^{\text {th }}$ century innovators, such as Henry Ford, created industrial powerhouses that used large numbers of uneducated laborers. The success of Detroit also meant that he success of its unionized labor force. By contrast, the innovations of Bill Gates or Sergey Brin primarily leads to the employment of more software engineers. The wizards of Wall Street similarly fail to employ large unskilled labor forces. Consequently, their success is watched from a distance by the poorer urbanites who remain in the city.

The millions made in finance and technology do generate jobs for the less skilled through urban service sectors, such as retail trade, leisure and hospitality. Yet these industries are much less 
capital-intensive and much more competitive than large scale manufacturing, and consequently much less amenable to unionization. These industries also proved particularly vulnerable to COVID-19. Autor (2019) documents that the returns to living in a big city have distinctly flattened for less skilled workers since the 1970s. This fact is particularly driven by the poor performance of cities with lower levels of education, where the less skilled are most likely to live (Glaeser, 2020).

Urban inequality rose substantially after 1980 (Glaeser, Resseger and Tobio, 2009), which might be tolerable if poor urban children are climbing into the middle class. Yet while cities generate wage growth for adults (Glaeser and Mare, 2001, DeLaRoca and Puga, 2017), but nchildren (Chetty et al., 2020). The Opportunity Atlas data assembled by Raj Chetty, John Friedman, Nathaniel Hendren and their co-authors tracks children born between 1978 and 1983, linking their earnings as adults with the earnings of their parents at the time when they were born. This linkage enables them to measure upward mobility across America and the results look particularly bad for cities.

Children of poor parents born in dense metropolitan areas or in denser neighborhoods within those areas are less likely to become rich as adults (Glaeser and Tan, 2021). Children born close to city centers are less likely to become rich as adults. Children who grow up right inside the central city school district are far more likely to be poor as adults and more likely to be incarcerated than those children who grow up right outside the central city school district. These spatial discontinuities suggest that America's urban schools deserve particular credit for producing the urban opportunity deficit.

The increasing wealth of the urban rich should help the poor by funding public schools, but it works against the interests of the poor through urban property markets. If the stock of housing in an area is relatively fixed, then rich and poor end up competing for the same housing units. As middle-class urbanites are priced out of better neighborhoods, they find space in poorer, grittier areas which then experience gentrification. Gentrification may be good for the owners of businesses and homes in the impacted area, but renters suffer from the increasing cost of their apartments. In cities like Los Angeles, the battles over gentrification have led to violence and destruction. 
Yet behind the conflict over gentrification lies another public failure: an insufficient supply of new housing. Nineteenth-century London and New York also experienced huge increases in the demand for living space which the cities met by erecting hundreds of thousands of new living units. Indeed, New York City permitted over 100,000 new units annually during the early 1920s. That abundant supply changed housing from a scarce commodity into a staple that is produced using less educated workers and capital. But since the 1960s, cities throughout the world have limited new construction through land use controls and historic preservation acts (Glaeser, Gyourko and Saks, 2005). These laws may well have preserved views and protected older neighborhoods from change, but they also limited the supply of new structures and ensured that urbanites spent more for their housing.

These outsiders are an example of a wider tendency towards protecting insiders at the expense of outsiders, which was particularly emphasized by Olsen (1983). Olsen's vision was that in a stable society, well-organized groups, such as teachers' unions or suburban homeowners' groups acquire power and enact rules to protect their own interests. Those rules then make it increasingly difficult for outsiders, such as the children of poor urbanites or would-be renters, to thrive. Cities have a massive array of regulations restricting new businesses as well as new buildings, which serve to protect existing businesses from competition. Occupational licensing, for jobs like selling flowers or being an interior decorator, are other forms of insider protection, that make it difficult to enter occupations or for members of those occupations to move across state borders.

A final and particularly important urban inequity occurs in urban policing, especially in the U.S. During the 1970s and 1980s, crime rates in big American cities skyrocketed. Cities responded by expanding their police forces, engaging in aggressive policing strategies such as "stop and frisk" and increasing sentence lengths, especially for repeat offenders who faced a wave of "three strikes and you're out" laws. Levitt (2001) estimates that the increased size of the police force played a significant role in reducing crime in New York City, but it is also possible that crime fell because of factors unrelated to policing or punishment, such as demographic change or abortion laws.

While poorer urbanites benefitted disproportionately from more recent reductions in crime rates, they have also suffered the costs of longer sentences and police actions. Millions of innocent people have been stopped and frisked. Thousands have been killed by the police. The Black Lives Matter phenomenon emerged as a hashtag in 2013 and grew into a movement, protesting police 
violence against African Americans. Anger at policing, and especially at the New York Police Department's handling of the Occupy Wall Street protests, meant that Mayor Bloomberg, a pragmatic centrist, was replaced with Mayor DeBlasio, a far more ideological figure. DeBlasio, as Public Advocate, had appeared with the protestors and opposed their eviction by Mayor Bloomberg.

Both the success of the urban rich and the failure of urban governments to address the needs of the poor, helped fracture cities before COVID-19. Those fractures exploded into massive protests after a white policeman killed a helpless African American in Minneapolis in 2020. As those protests had at least the potential to further spread COVID-19, they, theoretically at least, weakened America’s response to the pandemic. As Kahn (2005) found, disasters are generally more fatal in societies that are more fractured.

We have yet to fully see what the pandemic did to urban politics, but there are certain aspects of the pandemic which were profoundly unequal. Rich urbanites were typically able to telecommute. Poor urbanites were not. More than 68 percent of Americans with advanced degrees were working remotely in May of 2020. Less than fifteen percent of Americans with only a high school degree or less were working remotely in that same month. The wealthy often had the ability to relocate to a lower density locale, where it was more comfortable to wait out a lengthy quarantine. The children of the rich sometimes attended private schools, which continued offering in-person classes while public schools shut down.

The ability of the rich to seclude helps explain why they were so much less exposed to the disease, at least after the initial wave struck them by surprise. Glaeser, Gorback and Redding (2021) found that COVID-19 case rates in New York City and five other cities were strongly associated with mobility levels, which were in turn driven by occupation and industry. Poorer people who worked in drug stores and supermarkets were far more exposed to the disease than richer lawyers and accountants who worked from home.

The poor were also more likely to die, if they caught the disease, because of a greater prevalence of obesity and other co-morbidities among less well-educated individuals. Preliminary work by Raj Chetty and his collaborators finds that mortality rates for the rich did not even increase in 2020, while mortality rates for the poor rose dramatically. The dramatic health gap between rich and poor further divides the city and provides fuel for those who advocate significant 
redistribution. The accretion of all these divisions means that post-covid, America's cities, and many cities elsewhere, are particularly vulnerable.

\section{Risk \# 1: Zoom, Inequality and Empty Downtowns}

The most universal risk faced by the world's wealthier cities is that teleworking will become a permanent and significant part of the future of work and will massively reduce the demand for urban real estate. Forty-five million Americans were working remotely in June of 2020 (Bureau of Labor Statistics, 2021). By June of 2021, twenty-two million Americans were telecommuting. Almost thirty million workers have gone back to the office, but two-fifths of those who switched are still not back. If that persists, what will that mean for cities and their office markets? Does this have the potential to be the kind of economic shock that turns a physical disaster into a more permanent problem for cities?

Forty years ago, Alvin Toffler predicted a future full of teleworking in The Third Wave. He predicted that this would lead to empty skyscrapers and deserted downtowns. He predicted that office buildings would be converted into warehouse space. During the height of the pandemic, cities did indeed feel like ghost towns, but there are good reasons to be skeptical of such a pessimistic view for the future of downtowns.

There are at least four reasons to be somewhat doubtful about Toffler's vision coming true postCOVID. First, he was largely wrong for forty years before the COVID pandemic. Remote work has long been feasible and yet demand for urban office space remained largely robust. The technology companies that were most capable of allowing their workers to dial in, as the world saw during the COVID pandemic, did not do so. Instead, they agglomerated tightly in Silicon Valley (and Silicon Glens and Roundabouts) and they bought urban real estate. During 2020, Amazon, Apple, Facebook and Google all expanded their footprint in New York City, suggesting that they are expecting a world of enduring face-to-face interactions (Haag, 2020).

Second, the economic factors that drove the renaissance in many office markets since the 1970s have not disappeared. The post-industrial economy created enormous returns to skill and innovation. Face-to-face connection remains a critical means of acquiring new information, which 
is suggested by the fact that J.P. Morgan demanded that its traders come back to its trading floor in September 2020, long before the pandemic was over (Ambra Verlaine, 2020).

The weakness of Zoom as a platform for learning is suggested both by data on job postings for new hires and by the experience of on-line learning during the pandemic. Daboin and MoralesArilla (2020) examine the time series of employment and job postings for jobs that can and cannot be done remotely. They found that employment and posting in non-remote jobs plummeted during the first months of the pandemic, but both time series recovered by the summer of 2020. By contrast, employment stayed steady for jobs that could go remote, but new hiring plummeted and stayed down. One interpretation of these outcomes is that old work relationships could continue successfully via Zoom, but employers find it much harder to onboard new workers.

Emmanuel and Harrington (2021) find that when call-center workers go remote, they are just as productive in the short run, but they are far less likely to get promoted. When the workers aren’t in the office, they have less opportunity to learn from their fellow workers, and their managers have less ability to gauge the quality of their work. The at-home experience of actual students seems to have been particularly bleak. One evaluation of a natural experiment with remote learning in the Netherlands concludes that "despite favorable conditions, we find that students made little or no progress while learning from home” (Engzell, Frey and Verhagen, 2021).

Third, teleworking is not well suited for significant portions of the population, including those without much formal education, those who are just beginning their work lives or those who occupy cramped living quarters. In June 2021, 28 percent of adults with a college degree or more were still working remotely. Six percent of adults without a college degree were working remotely during that month. Only seven percent of 20-to-24-year-olds were working remotely in June of 2021 (Engzell, Frey, and Verhagen, 2021).

Fourth, predictions about the demise of the office market ignore the ability of office rents to adjust downward and attract new tenants. During the pandemic, commercial leasing activity plummeted but office rents (at least on paper) remained relatively stable. Before office towers go empty, landlords will cut rents. In markets like London, New York and San Francisco, where office rents were extremely high before 2020, even a 30 percent reduction in office rents will still leave landlords able to cover the operating costs of their office buildings. Such a radical reduction in 
rents will cause current tenants, who are thinking about going permanently remote, to reconsider and will lead other tenants, who had been priced out of these expensive markets, to enter.

The larger worry is that vacancies will skyrocket in markets, such as Cleveland and Detroit, where 2019 rents were much closer to the level needed to cover the landlord's operating costs. In these cases, landlords may well decide to walk away from properties rather than renting them at a loss. Rising vacancy levels may then ripple outward because an increase in the number of office vacancies mean a reduction in demand for the service providers, such as restaurants, that cater to nearby office workers.

The rise of telecommuting does suggest that many real estate developers may lose money and many cities will face a shrinking commercial property tax base. These are real issues, but they are not a widespread urban crisis. Nonetheless, individual cities are at risk, especially those that begin closer to the edge of survival, and every city now faces a more competitive market for businesses because the ability to relocate has never been easier.

\section{Risk \# 2: A political shift and an Urban Exodus}

During 2020, some neighborhoods in New York and San Francisco experienced a population decline of over five percent, at least as measured by change of address notices registered with the US Post Office. The permanent decline is likely to be far less, at least in those cities, because people will return, and prices will adjust to the point where apartments become occupied once more. Yet this urban exodus highlights the mobility of the rich and well-educated, which has been enabled by the ability to telecommute. Even if technology start-ups want to bring their workers together in an office, that office can easily be in Austin, Texas, or Boulder, Colorado. They can take more occasional meetings with their Silicon Valley-based venture capitalists over Zoom.

Such mobility increases the risk that a political push towards local redistribution will engender a population shift which will in turn further imperil local finances. This scenario replays the events

of the 1960s and 1970s. During those decades, heightened expectations about the need to right long-standing racial grievances and address social inequities led progressive mayors like Jerome Kavanagh in Detroit or John Lindsay in New York to adopt expensive, progressive policies. Yet at the very moment in which they were asking their citizens to pay more, highways were making 
it easier for those citizens to decamp to suburbs. Those highways and container ships were enabling urban factories to relocate to right-to-work states or to be replaced by foreign imports.

This combination of increased mobility and progressive urban politics produced the budget crises that afflicted many US cities during the 1970s. New York teetered on the edge of bankruptcy and the city government was essentially taken over by the Municipal Assistance Corporation, a statesponsored entity. Those fiscal crises led to a further deterioration in city services, and a new generation of managerial and pragmatic city-mayors, such as Rudy Giuliani in New York and Richard M. Daley of Chicago.

Post-pandemic, there will also be heightened mobility and a demand for progressive action. If progressive action means improving school management or eliminating unnecessary land use regulations, then there will be little risk of encouraging an emigration of taxpaying businesses and residents. However, if progressive action means increasing taxes or onerous regulations on business and the rich or failing to provide public safety, then this has the potential to induce an erosion of the tax base.

Holmes (1998) is the classic paper documenting the impact of local business climate on business growth. He uses a spatial discontinuity approach and compares pro-business and anti-business sides of state lines. His work finds a discrete and massive jump in manufacturing growth on the pro-business side of the line.

Giroud and Rauh (2019) estimate the impact of corporate income taxes on the location of jobs. They find that a three-percentage point rise in a state's top corporate tax rate is associated with a 1.5 percent decline in the number of establishments that are subject to the corporate income tax and a 1.2 percent decline in the number of jobs at such establishments. ${ }^{6}$ Pass-through corporations are subject to personal income taxes but not corporate income taxes. Increases in the state personal income tax reduces the number of "pass-through" corporate establishments and their employment.

The tendency of the rich to move in response to local income taxes is both documented and debated (Kleven et al., 2020, Young, 2020). Bakjia and Slemrod (2004) provided an earlier study of interstate relocation of the rich in response to estate taxes. Moretti and Wilson (2017) document that the location of American inventors is quite sensitive to local tax rates. Kleven et al. (2020)

\footnotetext{
${ }^{6}$ By taxed business establishment
} 
ably survey the literature and find significant support for the view that tax rates do shift locations, which leads them to consider coordinated rather than independent changes in the tax system.

As telecommuting seems to have increased mobility, the future sensitivity of the rich to local taxes may well be higher than these studies suggest. That possibility increases the risks associated with raising tax rates at the city or state level. In the US context, the coordination that Kleven et al. (2020) discuss is most naturally done at the Federal level, as Federal redistribution is unlikely to generate any migration response across states.

Yet most cities face institutional constraints that limit their ability to raise taxes to target the rich. Within the US, few cities have the power to tax income and must limit themselves to property taxes. In some states, including California and Massachusetts, their property tax rates were capped by popular referenda. Moreover, high property taxes seem unlikely to cause the rich to move out and the poor to move in, since a poor buyer would pay the same tax as a rich seller. Local taxing power is even more limited in the UK. The larger risk stems from local decisions that impact amenities like public safety.

\section{Risk \# 3: Crime returns to the city}

A final risk is that deteriorating amenity levels, such as declines in public safety, may reduce demand for living in cities. The urban renaissance of the 1990s, especially in New York, was associated with a massive reduction in crime rates. A safer city meant that millions of urbanites felt safer to enjoy shared urban amenities, like parks, and the fruits of urban entrepreneurship, like restaurants and late-night entertainment venues. If the high crime rates that many US cities experienced during 2020 become a recurring feature of urban life, then this will also present a challenge to post-COVID urban success. ${ }^{7}$

The successful fight to reduce urban crime during the 1990s and 2000s was accompanied by extremely empowered and aggressive police forces. The New York Police Department (NYPD), under Ray Kelly, conducted millions of stops of young men, particularly young men of color. The NYPD's hot spots policing strategy of targeting police resources to high crime areas seems to have

\footnotetext{
${ }^{7}$ This section focuses on the US, because homicide levels are far higher in many US cities than in their European equivalents.
} 
reduced crime in the targeted areas (Braga et al., 2019, MacDonald, et al., 2016). However, there is little evidence that stop-and-frisk did anything to reduce crime, and such aggressive tactics seem to have generated significant opposition to policing.

During 2020, the filmed murder of George Floyd helped galvanize a movement and motivated protests worldwide. Some of those protestors wanted to "defund the police." Politicians hear these voices, remember the past success of former public advocate Bill DeBlasio, and look for ways to satisfy understandably angry voters. Consequently, one political option for progressive politicians will be to significantly reduce police spending and use that money to fund their own preferred projects.

There are cases where some forms of non-police spending can effectively reduce crime, such as early childhood education, but gutting spending on policing creates the risk of rising crime levels. Following Levitt's (1997) pioneering work, there have been an abundance of studies, including the hot spots policing papers mentioned above, that have arguable established a causal link between increased police spending and reduced crime. There is no well-documented free lunch in policing that would allow us to reduce police spending levels without risking a return of high urban crime levels.

Even without reducing police spending, public outcries and investigations of police behavior can lead to significant increases in crime. Devi and Fryer (2020) estimate the impact of "federal and state 'Pattern or Practice' investigations on crime and policing." They find that these investigations lead police to avoid high crime areas and that crime rates increase dramatically after the police retreat. They conclude that investigations "preceded by 'viral”" incidents of deadly force," such as video of a police killing, "caused almost 900 excess homicides and almost 34,000 excess felonies.” Police wariness about COVID-19 also provides an explanation for the high crime rates that US cities experienced in 2020. Chicago's crime rate again rose to 29 murders per 100,000, which is the same level experienced in 2016. One possible reason is that police were avoiding ordinary contact with citizens that can help deter and investigate crimes. Not just the police but ordinary people were staying home and that meant fewer of the "eyes on the street," that Jane Jacobs emphasized were a crucial tool against crime. 
Most urbanites — rich and poor-want a police force that will keep them safe from harm and treat them with respect. There is no danger in sensible reforms, such as body cameras, that appear to improve police behavior (Braga et al., 2018). But either large-scale defunding or investigative policies that lead to significantly less police presence in high crime areas could lead to significant increases in urban crime. That crime could then further encourage the out-migration of the wealthy which can lead to lower tax revenues and less spending on police services and more crime. This is the third major risk facing America's cities post-COVID-19. This risk is far less serious outside the US, because local control over policing is more limited and because violence is less common.

\section{Conclusion}

The COVID-19 pandemic is the most extreme natural disaster in a century. The pandemic's ultimate impact on cities will also be determined by the strength of their governments and social institutions. The September 11, 2001, terrorist attacks on New York City did little to derail the urban renaissance of a relatively confident and united metropolis. But urban discontent has increased over the past 20 years (Glaeser, 2020) and in America our increasingly fractured cities are more vulnerable. That vulnerability was exposed during the George Floyd protests, where tens of thousands risked spreading and catching the virus in order to express their anger at brutal policing. On the other side of the political aisle, eschewing vaccines or a face mask became a way of showing one's love of liberty (Kahane, 2021).

In this paper, I have argued that cities have generally been robust both to events that destroy the physical environment, such as fires and bombing. Cities have survived pandemics that destroyed human capital as well. By contrast, economic and political shocks have often radically changed urban fortunes. Many cities in the US and UK are much less populous today than they were in 1950 because their erstwhile industries have relocated and mechanized. Pandemics and natural disasters only typically cause lasting urban damage when they then lead to political or economic change.

If the COVID-19 pandemic continues to be extremely deadly for many years or is soon followed by a second equivalent pandemic, then the disease may itself do considerable damage to the 
world's wealthy cities. Developing world cities are likely to continue to grow despite pandemics, just as western cities grew despite the $19^{\text {th }}$ century's outbreaks, because the demand for urban employment is so large when people are poor. But even if the pandemic ends relatively quickly, there are still economic and political dangers for urban life. Most obviously, the move to telecommuting seems to create significant challenges for the traditional model of face-to-face urban offices, and for the service economy that particularly employs less skilled urbanites.

In this essay, I have argued that some shift to remote work is inescapable, but that the forces that led to an urban economic rebirth since 1990 have not vanished. The returns to skill and innovation remain high and humanity is a social species that has evolved to learn from in-person meetings. Some office buildings may convert to residential uses and a shift from selling goods to selling experiences will continue, but in the medium run, cities with sky high demand for commercial space in 2019 will face space shortages again.

In the US, there are also political risks because progressive ambitions can collide with an increasingly mobile tax base. Telecommuting has made it far easier for the wealthy (but not the poor) to relocate to enclaves outside of big cities. If cities decide to tax the wealthy more aggressively or to provide fewer amenities, like public safety, then the rich will be more likely to flee. If businesses and the rich flee, affected city tax bases will decrease, and there will be less political opposition to the policies that the rich dislike. This scenario resembles the difficult 1970s when American cities faced significant out-migration, rising crime levels and budgetary woes.

Yet the longer run history of cities cannot help but make us optimistic. For 2500 years, urban connections have produced new technologies, great works of art and profound social change. For 1000 years, cities have survived bombings, the Black Death, cholera, earthquakes and fires. They have often built back better. While not every city will escape COVID-19 unscathed, most will surely thrive again. 


\section{References}

Ades, Alberto F., and Edward L. Glaeser. "Trade and circuses: explaining urban giants." The Quarterly Journal of Economics 110, no. 1 (1995): 195-227.

Ager, Philipp, Katherine Eriksson, Casper Worm Hansen, and Lars Lønstrup. "How the 1906 San Francisco earthquake shaped economic activity in the American West." Explorations in Economic History 77 (2020): 101342

Aldrich, Daniel P. "Social, not physical, infrastructure: the critical role of civil society after the 1923 Tokyo earthquake." Disasters 36, no. 3 (2012): 398-419.

Ambra-Verlaine, Julia. 2020. “JPMorgan Top Brass Tell Trading-Floor Staff to Come Back to the Office.” The Wall Street Journal, September, 2020. https://www.wsj.com/articles/jpmorgan-top-brass-telltrading-floor-staff-to-come-back-to-the-office-11599757313

Autor, David. Work of the Past, Work of the Future. No. w25588. National Bureau of Economic Research, 2019.

Bairoch, Paul. Cities and economic development: from the dawn of history to the present. University of Chicago Press, 1988.

Bakija, Jon, and Joel B. Slemrod. "Do the Rich Flee from High State Taxes? Evidence from Federal Estate Tax Returns." NBER Working Paper w10645 (2004).

Baum-Snow, Nathaniel. "Did highways cause suburbanization?." The quarterly journal of economics 122, no. 2 (2007): 775-805.

Braga, Anthony A., Brandon S. Turchan, Andrew V. Papachristos, and David M. Hureau. "Hot spots policing and crime reduction: an update of an ongoing systematic review and metaanalysis." Journal of experimental criminology 15, no. 3 (2019): 289-311.

Brainerd, Elizabeth and Mark Siegler (2003) “The Economics Effects of the 1918 Influenza Epidemic” Centre for Economic Policy Research Working Paper \# 3791.

Brakman, Steven, Harry Garretsen, and Marc Schramm. "The strategic bombing of German cities during World War II and its impact on city growth." Journal of Economic Geography 4, no. 2 (2004): 201-218.

Brueckner, Jan K., Jacques-Francois Thisse, and Yves Zenou. "Why is central Paris rich and downtown Detroit poor?: An amenity-based theory." European economic review 43, no. 1 (1999): 91-107.

Calderón, Alfonso. A memorial to Valparaíso. Ril Editores, 2001. 
Card, David, Alexandre Mas, and Jesse Rothstein. "Tipping and the Dynamics of Segregation." The Quarterly Journal of Economics 123, no. 1 (2008): 177-218.

Chandler, Tertius, and Gerald Fox. 3000 years of urban growth. Elsevier, 2013.

Charlier, Roger H. "The Zwin: from golden inlet to nature reserve." Journal of Coastal Research 27, no. 4 (2011): 746-756.

Chauvin, Juan Pablo, Edward Glaeser, Yueran Ma, and Kristina Tobio. "What is different about urbanization in rich and poor countries? Cities in Brazil, China, India and the United States." Journal of Urban Economics 98 (2017): 17-49.

Raj Chetty, Nathaniel Hendren, Maggie R Jones, Sonya R Porter, Race and Economic Opportunity in the United States: an Intergenerational Perspective, The Quarterly Journal of Economics, Volume 135, Issue 2, May 2020, Pages 711-783

Chippaux, Jean-Philippe, and Alain Chippaux. "Yellow fever in Africa and the Americas: a historical and epidemiological perspective." Journal of Venomous Animals and Toxins including Tropical Diseases 24 (2018).

Christakos, George, Ricardo A. Olea, Marc L. Serre, Lin-Lin Wang, and Hwa-Lung Yu. Interdisciplinary public health reasoning and epidemic modelling: the case of black death. New York: Springer, 2005.

Ciccone, Antonio. "Gibrat's Law for Cities: Evidence from World War I Casualties." (2021).

Collins, William J., and Robert A. Margo. "The economic aftermath of the 1960s riots in American cities: Evidence from property values." The Journal of Economic History 67, no. 4 (2007): 849-883.

Comfort, Nicholas A. The lost city of Dunwich. Terence Dalton, 1994.

Daboin, Carlos, Marcela Escobari, Gabriel Hernández, and José Morales-Arilla. "Economic Complexity and technological relatedness: findings for american cities." (2019).

Davis, Donald R., and David E. Weinstein. "Bones, bombs, and break points: the geography of economic activity." American economic review 92, no. 5 (2002): 1269-1289.

De La Roca, Jorge, and Diego Puga. "Learning by working in big cities." The Review of Economic Studies 84, no. 1 (2017): 106-142.

Devi, Tanaya, and Roland G. Fryer Jr. Policing the Police: The Impact of" Pattern-or-Practice" Investigations on Crime. No. w27324. National Bureau of Economic Research, 2020.

DiPasquale, Denise, and Edward L. Glaeser. "The Los Angeles riot and the economics of urban unrest." Journal of Urban Economics 43, no. 1 (1998): 52-78. 
Emmanuel, Natalie, and Emma Harrington. Working Paper. "'Working' Remotely? Selection, Treatment, and Market Provision of Remote Work (JMP)".

Engzell, Per, Arun Frey, and Mark D. Verhagen. "Learning loss due to school closures during the COVID19 pandemic." Proceedings of the National Academy of Sciences 118, no. 17 (2021).

Feigenbaum, James J., James Lee, and Filippo Mezzanotti. Capital Destruction and Economic Growth: The Effects of Sherman's March, 1850-1920. No. w25392. National Bureau of Economic Research, 2018.

Fluegge, Robert (2021) "The Legacy of a Pandemic: The Long-Run Effects of the 1918 Infuenza in the United States,” mimeographed.

Fuchs, G. and Wassermann, S., 2005. Path dependency in Baden-Württemberg: Lock-in or breakthrough?. In Rethinking regional innovation and change (pp. 223-248). Springer, New York, NY.

Giroud, Xavier, and Joshua Rauh. "State taxation and the reallocation of business activity: Evidence from establishment-level data." Journal of Political Economy 127, no. 3 (2019): 1262-1316.

Glaeser, Edward L. "Urbanization and its discontents." Eastern Economic Journal 46, no. 2 (2020): 191218.

Glaeser, Edward L., and Joseph Gyourko. "Urban decline and durable housing." Journal of political economy 113, no. 2 (2005): 345-375.

Glaeser, Edward L., Joseph Gyourko, and Albert Saiz. "Housing supply and housing bubbles." Journal of urban Economics 64, no. 2 (2008): 198-217.

Glaeser, E.L. and Mare, D.C., 2001. Cities and skills. Journal of labor economics, 19(2), pp.316-342.

Glaeser, Edward L., Matt Resseger, and Kristina Tobio. "Inequality in cities." Journal of Regional Science 49, no. 4 (2009): 617-646.

Glaeser, Edward L., José A. Scheinkman, and Andrei Shleifer. "Economic growth in a cross-section of cities." Journal of monetary economics 36, no. 1 (1995): 117-143.

Glaeser, Edward L., and Jesse M. Shapiro. "Cities and warfare: The impact of terrorism on urban form." Journal of Urban Economics 51, no. 2 (2002): 205-224.

Glaeser, Edward L., and Andrei Shleifer. "The Curley effect: The economics of shaping the electorate." Journal of Law, Economics, and Organization 21, no. 1 (2005): 1-19. 
Grodzins, Morton. "Metropolitan segregation." Scientific American 197, no. 4 (1957): 33-41.

Haag, Matthew. 2020. “Manhattan Emptied Out During the Pandemic. But Big Tech is Moving In.” The New York Times, October, 2020. https://www.nytimes.com/2020/10/13/nyregion/big-tech-nycoffice

Hall, Peter. "Enterprise zones: British origins, American adaptations." Built Environment 7, no. 1 (1981): 5.

Harding, Vanessa. "The population of London, 1550-1700: a review of the published evidence." The London Journal 15, no. 2 (1990): 111-128.

Harper, Kyle. "Pandemics and passages to late antiquity: Rethinking the plague of c. 249-270 described by Cyprian." Journal of Roman Archaeology 28 (2015): 223-260.

Hernon, Ian. The Wild East: Gunfights, Massacres and Race Riots Far From America's Frontier. Amberley Publishing Limited, 2019.

Hodges, Richard. "The riddle of St Peter's Republic." La storia economica di Roma nell'alto medioevo alla luce dei recenti scavi archeologici 356 (1993).

Holmes, Thomas J. "The Effect of State Policies on the Location of Manufacturing: Evidence from State Borders." Journal of Political Economy 106, no. 4 (1998): 667-705. Accessed August 4, 2021. doi:10.1086/250026.

Hornbeck, Richard, and Daniel Keniston. "Creative destruction: Barriers to urban growth and the Great Boston Fire of 1872." American Economic Review 107, no. 6 (2017): 1365-98.

Jedwab, Remi, Noel D. Johnson, and Mark Koyama. "Pandemics, places, and populations: Evidence from the Black Death." (2019).

Kahane, Leo H. "Politicizing the mask: Political, economic and demographic factors affecting mask wearing behavior in the usa." Eastern economic journal 47, no. 2 (2021): 163-183.

Kahn, Matthew E. "The death toll from natural disasters: the role of income, geography, and institutions." Review of economics and statistics 87, no. 2 (2005): 271-284.

Kleven, Henrik, Camille Landais, Mathilde Muñoz, and Stefanie Stantcheva. 2020. "Taxation and Migration: Evidence and Policy Implications." Journal of Economic Perspectives, 34 (2): 119-42. 
Levitt, Steven D. "Using electoral cycles in police hiring to estimate the effect of police on crime." The American Economic Review 87, no. 3 (1997): 270.

Lindell, Michael K. "Built-in resilience." Nature Geoscience 3, no. 11 (2010): 739-740.

Littman, Robert J. "The plague of Athens: epidemiology and paleopathology." Mount Sinai Journal of Medicine: A Journal of Translational and Personalized Medicine: A Journal of Translational and Personalized Medicine 76, no. 5 (2009): 456-467.

Littman, Robert J., and Maxwell L. Littman. "Galen and the Antonine plague." The American Journal of Philology 94, no. 3 (1973): 243-255.

Lo Cascio, E. 'Fra equilibrio e crisi’ in A. Schiavone (ed.), Storia di Roma II.2 (Torino 1991), 701-731.

MacDonald, John, Jeffrey Fagan, and Amanda Geller. "The effects of local police surges on crime and arrests in New York City." PLoS one 11, no. 6 (2016): e0157223.

Miguel, Edward, and Gerard Roland. "The long-run impact of bombing Vietnam." Journal of development Economics 96, no. 1 (2011): 1-15.

Mordechai, Lee, Merle Eisenberg, Timothy P. Newfield, Adam Izdebski, Janet E. Kay, and Hendrik Poinar. "The Justinianic Plague: an inconsequential pandemic?." Proceedings of the National Academy of Sciences 116, no. 51 (2019): 25546-25554.

Moretti, Enrico. "Estimating the social return to higher education: evidence from longitudinal and repeated cross-sectional data." Journal of econometrics 121, no. 1-2 (2004): 175-212.

Moretti, Enrico, and Daniel J. Wilson. "The effect of state taxes on the geographical location of top earners: Evidence from star scientists." American Economic Review 107, no. 7 (2017): 1858-1903.

O’Connor, Maura R. 2012. “Two Years Later, Haitian Earthquake Death Toll in Dispute.” Columbia Journal Review, January, 2012.

https://archives.cjr.org/behind_the_news/one_year_later_haitian_earthqu.php

Pauly, John J. "The great Chicago fire as a national event." American Quarterly 36, no. 5 (1984): 668683.

Pereira, Alvaro S. "The opportunity of a disaster: The economic impact of the 1755 Lisbon earthquake." The Journal of Economic History 69, no. 2 (2009): 466-499. 
Pye, Kenneth, and Simon J. Blott. "Coastal processes and morphological change in the Dunwich-Sizewell area, Suffolk, UK." Journal of Coastal Research 22, no. 3 (2006): 453-473.

Redding, Stephen J., Edward L. Glaeser, and Caitlin Gorback. "How Much Does COVID-19 Increase with Mobility? Evidence from New York and Four Other US Cities." (2020).

Rosenberg, Charles E. The cholera years: The United States in 1832, 1849, and 1866. University of Chicago Press, 2009.

Sabbatani, Sergio, and Sirio Fiorino. "The Antonine Plague and the decline of the Roman Empire." Le Infezioni in medicina 17, no. 4 (2009): 261-275.

Schelling, Thomas C. "Dynamic models of segregation." Journal of mathematical sociology 1, no. 2 (1971): 143-186.

Schencking, J. Charles. "Catastrophe, opportunism, contestation: The fractured politics of reconstructing Tokyo following the great Kantô earthquake of 1923." Modern Asian Studies 40, no. 4 (2006): 833-873.

Shapiro, Jesse M. "Smart cities: quality of life, productivity, and the growth effects of human capital." The review of economics and statistics 88, no. 2 (2006): 324-335.

Sheppard, Francis Henry Wollaston. London: a history. Oxford University Press, USA, 1998.

Thucydides. History of the Peloponnesian War. Edited Finley. Translated by Rex Warner: London: Penguin Books, 1974.

Tittler, Robert. "Reconsidering the "English Urban Renaissance": Cities, Culture, and Society after the Great Fire of London-Building the Georgian City. By James Ayres. New Haven, Conn., and London: Yale University Press, 1998. Pp. vii+ 280. 64.95." Journal of British Studies 40, no. 3 (2001): 419-430.

Tran, Brigitte Roth, and Daniel J. Wilson. "The local economic impact of natural disasters." Federal Reserve Bank of San Francisco, 2020.

Tokyo Metropolitan Government. 2018. Tokyo's History, Geography, and Population. Tokyo Metropolitical Government Document. Tokyo. 
United Nations Department of Economic and Social Affairs. 1969. Growth of the World's Urban and Rural Population, 1920-2000.

United States Bureau of Labor Statistics. 2021. Supplemental data measuring the effects of the coronavirus (COVID-19) pandemic on the labor market.

Van der Woude, Ad M. "Population Developments in the Northern Netherlands (1500-1800) and the Validity of the Urban Graveyard Effect” In 1982, pp. 55-76. De Gruyter Mouton, 2020.

Velde, Francois R. "What happened to the US economy during the 1918 influenza pandemic? A view through high-frequency data." (2020).

Wagner, David M., Jennifer Klunk, Michaela Harbeck, Alison Devault, Nicholas Waglechner, Jason W. Sahl, Jacob Enk et al. "Yersinia pestis and the Plague of Justinian 541-543 AD: a genomic analysis." The Lancet infectious diseases 14, no. 4 (2014): 319-326.

Wilson, Charles H. "The economic decline of the Netherlands." The Economic History Review 9, no. 2 (1939): 111-127.

Young, Cristobal. The Myth of Millionaire Tax Flight. Stanford University Press, 2020. 